\title{
Role of fish herbivory in structuring the vertical distribution of canopy algae Cystoseira spp. in the Mediterranean Sea
}

\author{
Adriana Vergés ${ }^{1,2, *}$, Teresa Alcoverro ${ }^{2}$, Enric Ballesteros ${ }^{2}$ \\ ${ }^{1}$ Centre for Marine Ecosystems Research, School of Natural Sciences, Edith Cowan University, 100 Joondalup Drive, \\ Joondalup, Western Australia 6027, Australia \\ ${ }^{2}$ Centre d'Estudis Avançats de Blanes (CSIC), Accés a la Cala Sant Francesc 14, 17300 Blanes, Girona, Spain
}

ABSTRACT: Biological interactions can strongly influence the distribution of organisms. In the Mediterranean Sea, macroherbivore densities vary with depth in a highly predictable manner, but the direct effects of grazing on the vertical distribution of macrophytes remain largely unknown. Species of the genus Cystoseira provide a unique system in which to test the effects of herbivores on algal distribution in the Mediterranean Sea, since they form highly prominent forest-like assemblages along the entire sublittoral zone, with different species dominating the canopy at different depths. We measured the algal cover of $C y s-$ toseira spp. in habitats characterised by dominance of these algae at different depths, and quantified the density of herbivorous fish at each habitat. The shallow sublittoral (ca. $5 \mathrm{~m}$ ) was the only habitat where abundant Cystoseira forests coexisted with high densities of herbivorous fish. Reciprocal in situ feeding experiments showed that Cystoseira spp. from wave exposed shores $(0 \mathrm{~m})$ and deep habitats $(40 \mathrm{~m})$ are highly susceptible to being eaten when placed within reach of herbivorous fish and are, thus, restricted to spatial refuges with locally reduced herbivory. In contrast, Cystoseira spp. from shallow rocky bottoms $(5 \mathrm{~m})$ and wave sheltered shores $(0.2 \mathrm{~m})$ are resistant to consumers and are not affected by transplantation to areas of high fish densities. Our findings challenge the widely accepted view that herbivorous fish have only a modest effect on structuring algal assemblages in temperate waters and show that these consumers can have a particularly important effect on the vertical distribution of algal assemblages in the Mediterranean Sea.

KEY WORDS: Community structure $\cdot$ Distribution patterns · Plant-herbivore interaction - Sarpa salpa . Fucales $\cdot$ Herbivore resistance $\cdot$ Cystoseira spp.

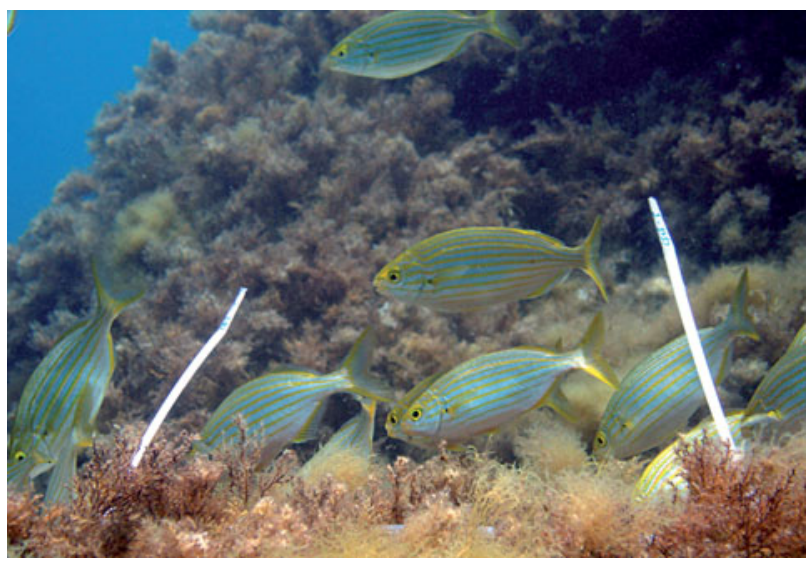

The sparid Sarpa salpa is a key primary consumer in the NW Mediterranean.

Photo: Adriana Vergés

\section{INTRODUCTION}

Multiple physical variables such as temperature, light and resource availability interact with features from the biotic environment, such as predation and competition, to determine the patterns of spatial distribution of species. Such factors operate at a variety of scales ranging from large biogeographical processes to regional and local mechanisms. In marine communities, historical and evolutionary processes as well as temperature and ocean currents often determine species distribution at large biogeographical scales (Hutchins 1947, Gaylord \& Gaines 2000, Briggs 2007). At a regional scale, factors such as degree of wave exposure, benthic topography and salinity are often the most important determinants of species composition (Little \& Kitching 1996). On a local scale, marine 
benthic species are often distributed in distinct vertical patterns. Physical factors such as desiccation and heat stress commonly limit the upward extension of many species, whilst light and biological interactions frequently determine lower range boundaries (Witman \& Dayton 2001).

In sublittoral communities, herbivory is one of the most important mechanisms determining macrophyte species abundance and distribution (Cyr \& Pace 1993, Burkepile \& Hay 2006). In particular, depth gradients in herbivory can strongly contribute to the vertical distribution of macrophytes in both temperate and tropical systems by limiting the downward distribution of species (Witman 1987, Morrison 1988). Consumer pressure is usually lowest at shallow, wave exposed locations, because wave impact and extreme water movement reduce the feeding ability and survival of most mobile consumers (Witman \& Dayton 2001). Conversely, herbivore pressure is often greatest a few metres below the surface and decreases thereafter with depth (Hay et al. 1983). Thus, some zones along the depth gradient of rocky shores represent refuges from consumers, and such spatial heterogeneity in herbivory can strongly contribute to the regional diversity of macrophytes (Milchunas \& Noy-Meir 2002). This spatial escape from consumers protects algae from the negative effects of herbivory (Lubchenco \& Gaines 1981). In contrast, macrophytes that do not succeed in escaping herbivores defend themselves against consumers via either resistance mechanisms (i.e. chemical deterrents and structural defences) or tolerance strategies (e.g. compensatory growth and activation of dormant meristems) (Lubchenco \& Gaines 1981).

The Mediterranean Sea is essentially a tideless sea (tidal range: 30 to $40 \mathrm{~cm}$ ), and consequently sea level varies more as a result of irregular changes in barometric pressure or the direction and force of the wind than as a result of tidal action (Feldmann 1937, Ballesteros \& Romero 1988). Despite this narrow tidal range, algal communities are distributed in strikingly marked vertical zonation patterns (Ballesteros 1992), which are largely determined by multiple depth-dependent physical factors such as light, hydrodynamism and availability of nutrients (Zabala \& Ballesteros 1989, Ballesteros et al. 1993). Biotic factors such as recruitment and species interactions are also important in structuring algal communities (Airoldi 2000, Micheli et al. 2005). In particular, herbivores play a major role in the organization of the Mediterranean sublittoral zone (Ruitton et al. 2000). Sea urchins have dramatically altered the underwater seascape by replacing erect algal assemblages with coralline barren grounds in many areas (Sala et al. 1998) and contribute most to the decline of palatable algae (Hereu 2006). Despite such examples of the overarching effect of herbivores on benthic assemblages, there is only limited evidence of grazing directly influencing vertical algal zonation in the Mediterranean Sea (Benedetti-Cecchi et al. 2000). This lack of evidence is particularly surprising as both fish and urchin herbivory varies bathymetrically in a highly predictable manner, with maximum values occurring in shallow waters (Verlaque 1990, Chelazzi et al. 1997, Tomas et al. 2005).

The genus Cystoseira C. Agardh (Fucales, Phaeophyceae) is particularly well represented in the Mediterranean Sea (32 species from a total of 47; Guiry \& Guiry 2008). Mediterranean Cystoseira spp. form highly prominent canopies that are in many ways analogous to the kelp forests of other temperate rocky coasts (Feldmann 1937, Giaccone 1973, Ballesteros et al. 1998). Cystoseira forests provide a unique system in which to test the effects of herbivory on algal zonation, since they are distributed along the entire sublittoral zone, with different species dominating the canopy at various bathymetric levels from the sea surface interface to the upper circalittoral zone (0 to $50 \mathrm{~m}$ depth) (Giaccone \& Bruni 1973, Sant 2003). Many members of the genus Cystoseira are considered foundation species (sensu Dayton 1972), and depletion of these populations results in a conspicuous reduction of species diversity over extensive areas (Verlaque 1987a,b, Boudouresque et al. 1990). Although the demise of Cystoseira forests due to overgrazing by sea urchins has been well documented (Verlaque 1984, 1987b, Hereu 2004), we know little about the effects of fish herbivory on Cystoseira populations. However, Cystoseira spp. can make up to $60 \%$ of the gut contents of the sparid bream Sarpa salpa (Linnaeus), the only true herbivorous fish in the western Mediterranean Sea (Verlaque 1990), and recent evidence suggests that fishes can have a significant influence on the structuring of Mediterranean sublittoral algal communities (Sala \& Boudouresque 1997, Hereu 2006).

In the present study, we experimentally tested the role of fish herbivory in determining the depth distribution of Cystoseira forests. We identified 4 distinct habitats arranged along a bathymetric gradient that are characterised by the dominance of different species of Cystoseira: (1) the eulittoral at mean sea level in wave exposed sites, hereafter referred to as 'exposed', (2) the upper sublittoral just below the sea surface at about $0.2 \mathrm{~m}$ in wave sheltered sites, referred to as 'sheltered', (3) the shallow sublittoral at about $5 \mathrm{~m}$ depth, referred to as 'shallow', and (4) the upper circalittoral at $40 \mathrm{~m}$ depth, referred to as 'deep'. We obtained a quantitative profile of the depth distribution of all Cystoseira spp. by measuring their abundance at each of these habitats, and we quantified the density of Sarpa salpa at each habitat. We found 3 habitats where Cystoseira spp. are dominant and fish densities are 
extremely low (exposed, sheltered and deep), and one habitat where Cystoseira forests coexist with herbivorous fish (shallow). We hypothesized that the exposed, sheltered and deep habitats represent spatial refuges from consumers, and Cystoseira spp. that are exclusively found in these habitats do not invest resources in traits that confer resistance to consumers and are, thus, highly susceptible to being eaten if transplanted to habitats with high herbivore pressure. In contrast, we predicted that Cystoseira spp. found in habitats where herbivorous fish abound would be less susceptible to being eaten. To test this hypothesis, we conducted a series of reciprocal in situ feeding experiments whereby the most abundant species of Cystoseira from exposed, sheltered and deep habitats were placed back in their site of origin and in the nearest shallow habitat with high fish herbivory pressure, and we compared consumption rates between habitats and species. Additionally, we used feeding preference experiments to assess the relative palatability of 2 Cystoseira spp. that co-exist with herbivorous fish.

\section{MATERIALS AND METHODS}

Study site. This study was performed in a Marine Protected Area (MPA) located along the north coast of the island of Menorca (Reserva Marina del Nord de Menorca) in the Balearic Islands (NW Mediterranean Sea; Fig. 1). This MPA was established in 1999 and covers 5119 ha that consist mostly of rocky bottoms $(40 \%)$, seagrass meadows $(20 \%)$ and sandy bottoms $(35 \%)$ (Ballesteros \& Cebrian 2004). The waters that surround the Balearic Islands are extremely oligo- trophic, leading to high water transparency and the presence of communities dominated by erect algae and/or seagrasses to $40 \mathrm{~m}$ depth (Ballesteros et al. 1993). The 4 habitats at distinct depths characterised by the dominance of different Cystoseira spp. are illustrated in Fig. 2. The exposed habitat at mean sea level in wave exposed sites $(0 \mathrm{~m})$ experiences the highest hydrodynamism and encounters regular emersion as a result of wave movements. The sheltered habitat is found just below the sea surface in wave sheltered areas $(0.1$ to $0.5 \mathrm{~m})$ and is characterised by calm waters that can reach high temperatures in the summer due to the lack of wave action and low water renewal. The shallow sublittoral habitat at about $5 \mathrm{~m}$ depth is characterised by a stable environment and relatively high irradiance levels. The deep habitat is found in the upper circalittoral zone at about $40 \mathrm{~m}$ depth; it is located below the summer thermocline and is, thus, characterised by relatively cold waters and low irradiances (Ballesteros \& Zabala 1993).

Field surveys. To obtain a profile of the depth distribution of species belonging to the genus Cystoseira, we quantified algal cover using depth transects. In exposed and sheltered shores, the algal cover of all Cystoseira spp. was measured at a range of depths from 0 to $5 \mathrm{~m}$. Specifically, algal cover in exposed shores was measured at $0,0.2,0.4,2$ and $5 \mathrm{~m}$. In sheltered shores there were no algae growing at $0 \mathrm{~m}$, and algal cover was measured at $0.2,0.4,2$ and $5 \mathrm{~m}$. At the deep habitat algal cover was measured at $40 \mathrm{~m}$, and at $5 \mathrm{~m}$ in the nearest shallow habitat. Transects were performed in 3 replicate sites for each exposed, sheltered and deep habitat (see Fig. 1). We used $25 \times 25 \mathrm{~cm}$ quadrats subdivided into 25 subquadrats of $5 \times 5 \mathrm{~cm}$

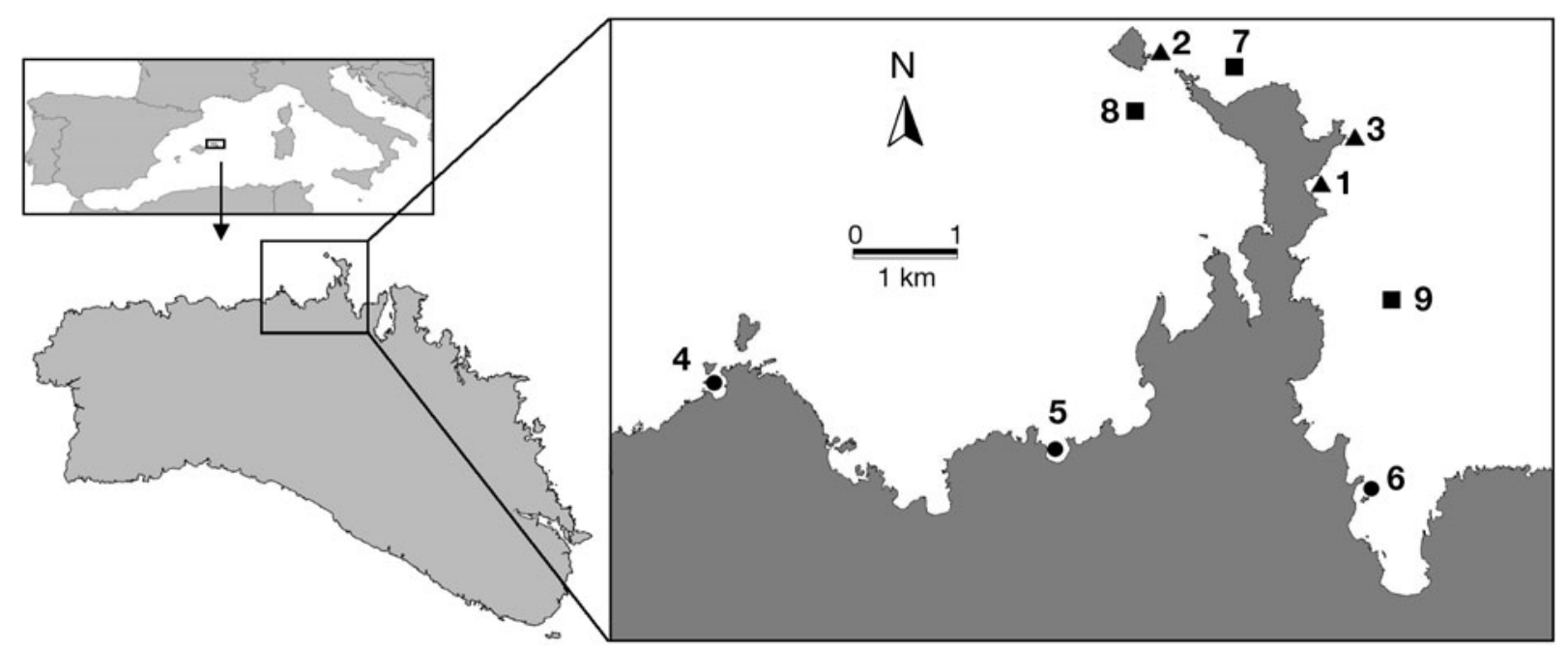

Fig. 1. Location of the study sites (right panel) inside the Nord de Menorca MPA (box in lower left panel), in the NW Mediterranean Sea (upper left panel). (^) Exposed sites: 1, Dins Es Guix; 2, Illa dels Porros; 3, Llosa del Patró Pere. (•) Sheltered sites: 4, Cala Barril; 5, Cala Mica; 6, Illots de Tirant. (匹) Deep sites: 7, Cavalleria; 8, Sa Nitja; 9, Tirant 


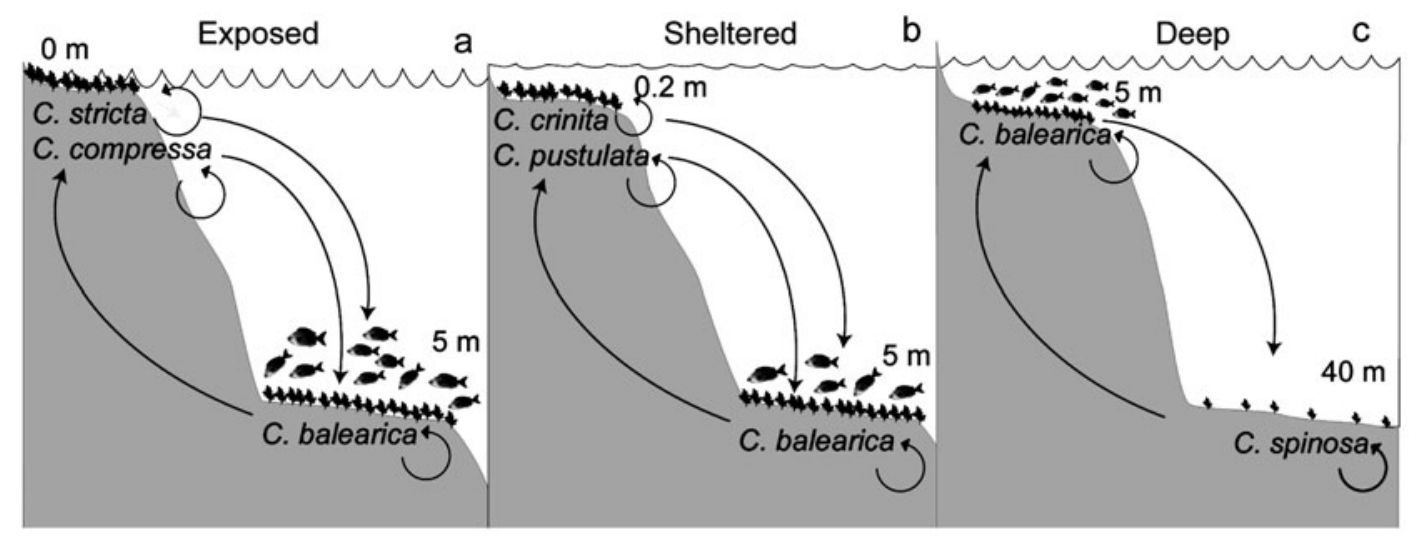

Fig. 2. Cystoseira spp. Schematic representation of the 3 reciprocal in situ feeding experiments performed showing the dominant species at each depth (exposed and sheltered shores and deep waters). Cystoseira spp. found at depths characterised by low fish densities were placed back in their habitat of origin and in the nearest zone at $5 \mathrm{~m}$ depth. Species found at depths where fish were abundant were also placed back in their original habitat and in the corresponding contiguous habitat with low fish densities

each and calculated algal cover by counting the number of subquadrats in which a species appeared (Sala \& Ballesteros 1997). Algal cover was measured in 40 random quadrats at all sites and depths except at the deep habitat $(40 \mathrm{~m})$, where we used 100 replicate quadrats to compensate for the sparseness of the algal cover at that depth. The most abundant species from each habitat were subsequently used in the reciprocal in situ feeding experiments.

To relate algal distribution to consumer pressure, we quantified the density of the sparid bream Sarpa salpa at each habitat (exposed, sheltered, shallow and deep). $S$. salpa is the only true herbivorous fish in the NW Mediterranean Sea and is a key consumer of both algae and seagrasses (Verlaque 1990, Ruitton et al. 2006, Prado et al. 2007). S. salpa densities were quantified at each habitat using the stationary point method (Sala \& Ballesteros 1997). The observer remained stationary at a random location and recorded the number of $S$. salpa individuals in a radius of $10 \mathrm{~m}$ during $5 \mathrm{~min}$. Only medium and large sized fish $(>15 \mathrm{~cm})$ were counted, and fish counts were replicated 6 times at each site within a period of $2 \mathrm{wk}$ in June. Observers were SCUBA diving in all habitats except at mean sea level in exposed shores $(0 \mathrm{~m})$ and at $0.2 \mathrm{~m}$ in sheltered shores, where the observer was snorkelling. Fish counts were always performed around noon (10:00 to 15:00 h).

Reciprocal in situ feeding experiments. A series of reciprocal feeding experiments in situ were used to test the hypothesis that fish herbivory influences the habitat distribution of some species of Cystoseira. We used the algal field surveys to identify the most abundant Cystoseira spp. at each habitat (see Fig. 3), and the data from the fish surveys to identify those habitats with the highest fish densities. Fish were only found in the shallow habitat $(5 \mathrm{~m}$ depth, see 'Results - Field surveys'), and we therefore considered that all other habitats represent potential refuges from herbivory. We subsequently performed 3 types of reciprocal in situ feeding experiments, one for each low herbivory habitat (exposed, sheltered and deep). In each reciprocal feeding experiment, algae were placed at 2 depths: one where we found no herbivorous fish $10 \mathrm{~m}$ in exposed shores, $0.2 \mathrm{~m}$ in sheltered shores and $40 \mathrm{~m}$ in deep water) and one where fish were present (shallow habitats at $5 \mathrm{~m}$ adjoining each exposed, sheltered and deep site; see schematic representation in Fig. 2). Each Cystoseira spp. was, thus, translocated back to its original habitat and depth (origin experimental depth) and placed at a depth outside of its natural range of distribution (destination experimental depth). Reciprocal feeding experiments were replicated in 3 separate sites for each exposed, sheltered and deep habitat, using the same sites as in the field surveys (Fig. 1). The experimental design thus included the following factors: (1) experimental depth (2 levels in all experiments, origin and destination), (2) site (3 levels in all experiments), and (3) species (3 levels in 'exposed': C. stricta, C. compressa and C. balearica; 3 levels in 'sheltered': C. crinita, C. pustulata, C. balearica; 2 levels in 'deep': C. spinosa and C. balearica).

Algae were collected from their respective natural habitats and transported to the laboratory where they were blot-dried, weighed to the nearest $0.1 \mathrm{~g}$ wet wt and individually tagged. Special care was taken to collect algae from the holdfast without damaging the thallus. In each experiment, 10 algal specimens of each species were transplanted to a destination experimental depth and 10 algal specimens were translocated back to their origin experimental depth. Translocated specimens were not placed back in their original position, but were instead moved within the original habi- 
tat and depth. To control for autogenic changes in algal biomass, 10 control specimens for each species were individually protected from herbivores with plastic window-screen mesh cages ( $3 \mathrm{~mm}$ mesh size); these were also transplanted to both their habitat of origin and to an adjacent destination habitat. Very little autogenic change was documented (maximum change of $\pm 5 \%$ initial control biomass). Specimens were transplanted and translocated by haphazardly tethering them to other macrophytes using plastic cable ties. To standardise replicates, we used specimens of similar initial weights for all species. Algal herbivory was calculated by subtracting the change in biomass of a treatment specimen from the change in a paired control specimen (Uncaged - Caged). The experiments were set up in the morning and retrieved after $24 \mathrm{~h}$ if clear marks of consumption were observed or after a maximum of $48 \mathrm{~h}$. To ensure that all herbivory was due to fish consumption, we manually removed any sea urchins found close to experimental specimens.

Feeding preference experiments. The results from the field surveys and the reciprocal in situ feeding experiments led to additional feeding experiments where we measured the relative palatability of $2 \mathrm{Cys}-$ toseira spp. In the first bioassay, we assessed the palatability of $C$. balearica, the main Cystoseira sp. found where herbivorous fish abound. To measure its relative palatability we compared it with another dominant macrophyte found at similar depths, the seagrass Posidonia oceanica (L.) Delile. P. oceanica is an important dietary component of the fish Sarpa salpa (Prado et al. 2007) and is the most abundant macrophyte at $5 \mathrm{~m}$ depth in our study sites, where it can be found within 0 to $10 \mathrm{~m}$ from $C$. balearica. Since $C$. balearica is the only Cystoseira sp. that abounds in habitats with high densities of $S$. salpa, we predicted that it would be less susceptible to being eaten than would the known components of the diet of this fish.

In the second bioassay, we aimed to determine the relative palatability of Cystoseira pustulata, a dominant species in sheltered shores. Of the species found naturally in this habitat, C. pustulata was the most highly consumed species (see 'Results - Reciprocal in situ feeding experiments'). Nevertheless, the overall biomass lost to herbivores was much lower than that lost by Cystoseira species from either exposed or deep habitats placed on shallow habitats. Since fish densities are lower at $5 \mathrm{~m}$ in sheltered inlets than at $5 \mathrm{~m}$ depth near exposed shores (see 'Results - Field surveys'), we wanted to determine whether the observed overall low consumption values were due to low herbivore pressure or to the unpalatability of $C$. pustulata. In this second bioassay we offered fish a choice between the sheltered species $C$. pustulata and the taxonomically related exposed species C. compressa.
In both field experiments, the 2 macrophytes were offered in pairs in sandy patches at least $5 \mathrm{~m}$ away from seagrass meadows and rocky reefs, so that we could be sure that the fish were choosing between the 2 target food choices and not other surrounding macrophytes. Experiments were deployed in the morning and collected after $24 \mathrm{~h}$. Replicate pairs were at least $3 \mathrm{~m}$ apart from each other. Control replicate pairs ( $\mathrm{n}=$ 10) were individually protected from herbivores with plastic mesh cages (1 cm mesh size), and we used an equal number of no-herbivore (caged) controls as replicates. In the feeding preference experiment between Cystoseira balearica and Posidonia oceanica, macrophytes were photographed at the beginning and at the end of the experiment, and consumption was measured as changes in area determined using ImageJ image analysis software (available online at rsb.info. nih.gov/ij). In the feeding experiment between C. compressa and C. pustulata, consumption was measured as the change in biomass before and after the experiment. In all experiments, similar initial macrophyte areas or weights were offered to herbivores.

Statistical analyses. Since Sarpa salpa was only observed in shallow habitats ( $5 \mathrm{~m}$ depth, see 'Results Field surveys'), we compared fish density counts $(n=6)$ between the shallow habitats contiguous to all other habitat types. Differences in fish densities were assessed with a 2-way nested ANOVA, with contiguous habitat type as a fixed factor and site as a random factor nested within contiguous habitat type.

We used a separate 3-way ANOVA for each reciprocal feeding experiment (exposed, sheltered and deep) to assess the differences in biomass consumed between species and experimental depths at all sites. Site was considered as a random factor and experimental depth and species as fixed factors. Post hoc comparisons were made using Student-Newman-Keuls (SNK) multiple comparison tests when required. ANOVAs were performed using the statistical package GMAV5 (coded by A. J. Underwood and M. G. Chapman, University of Sydney, Australia). Differences in feeding in paired preference assays were analyzed using $t$-tests as outlined by Peterson \& Renaud (1989). The $t$-statistic was calculated by comparing the between-food differences in mass per area change of treatment replicates (Choice 1 - Choice 2, with herbivores) to control replicates (Choice 1 - Choice 2, without herbivores). All data were checked for normality and equality of variances by visual inspection of scatterplots and distribution of residuals (Quinn \& Keough 2002). We found some departures from these assumptions that could not be fixed through transformation, but the relatively large number of replicates in our analyses led us to consider ANOVA robust enough to compensate for these departures (Underwood 1997). 
Table 1. Cystoseira spp. found at each habitat including the taxonomic naming authorities and the abbreviated name used throughout the text. The dominant species in each habitat used in the reciprocal in situ feeding experiments are in bold text

\begin{tabular}{|lll|}
\hline Habitat & Species & Referred to as: \\
\hline Exposed $(0 \mathrm{~m})$ & C. amentacea Bory var. stricta Montagne & C. stricta \\
& C. compressa (Esper) Gerloff \& Nizamuddin var. compressa & C. compressa \\
Sheltered $(0.2 \mathrm{~m})$ & C. compressa (Esper) Gerloff \& Nizamuddin var. pustulata Ercegovic & C. pustulata \\
& C. crinita (Desf.) Bory & C. crinita \\
& C. spinosa Sauvageau var. tenuior (Ercegovic) Cormaci et al. & C. tenuior \\
C. foeniculacea (L.) Grev. f. tenuiramosa (Ercegovic) Gómez et al. & C. tenuiramosa \\
Shallow $(5 \mathrm{~m})$ & C. brachycarpa J. Agardh var. balearica (Sauvageau) Giaccone & C. balearica \\
& C. spinosa Sauvageau var. compressa (Ercegovic) Cormaci et al. & C. spinosa \\
& C. foeniculacea (L.) Grev. f. latiramosa (Ercegovic) Gómez et al. & C. latiramosa \\
& C. zosteroides (Turner) C. Agardh & C. zosteroides \\
\hline
\end{tabular}

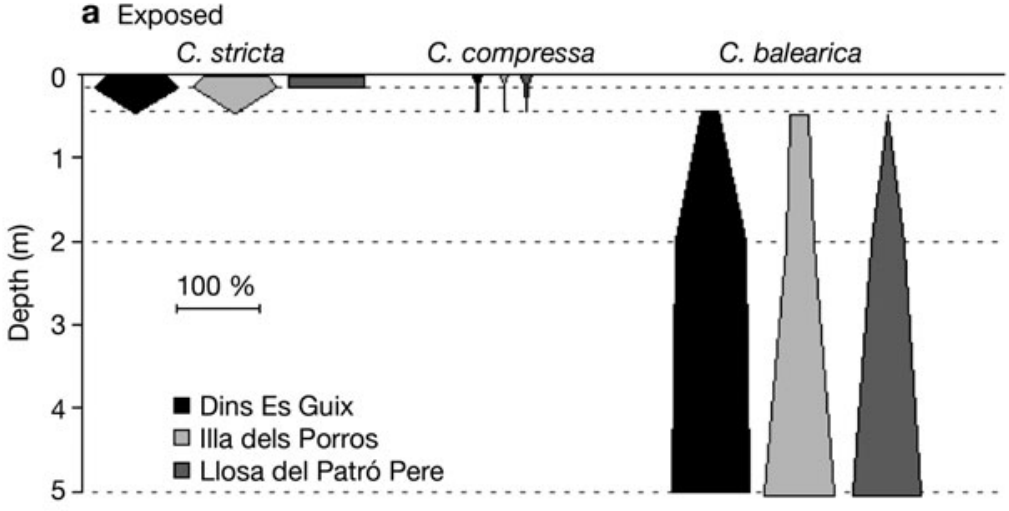

b Sheltered

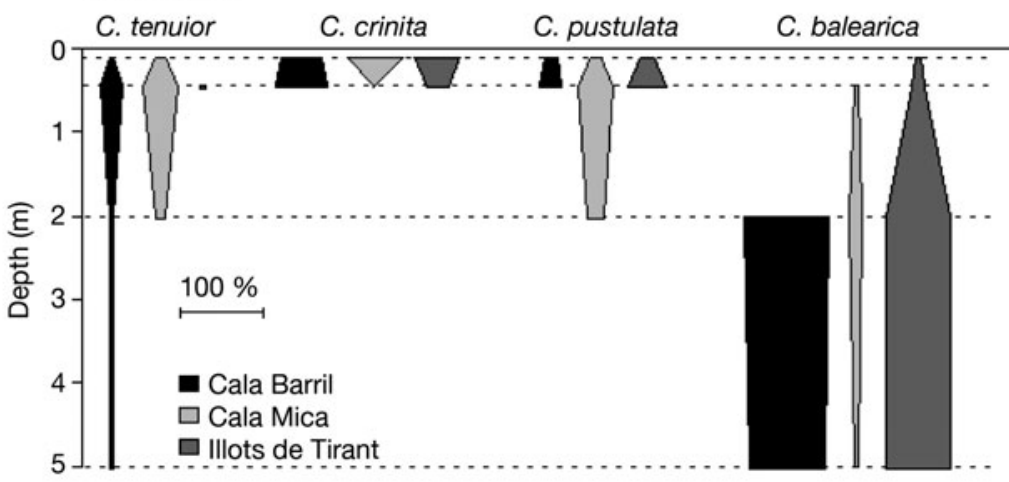

c Deep

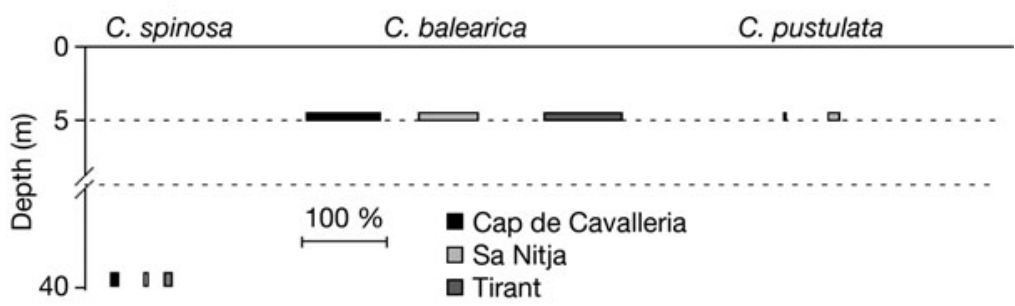

Fig. 3. Cystoseira spp. Vertical distribution of species in each of the 3 sites in (A) exposed shores, (B) sheltered shores and (C) deep waters. Algal cover of each species is represented to scale. Only algal cover $\geq 5 \%$ are represented. At the deep habitats the Cystoseira cover was only measured at $40 \mathrm{~m}$ depth, and at $5 \mathrm{~m}$ depth in the nearest shallow habitat

\section{RESULTS}

\section{Field surveys}

We found 10 Cystoseira species/taxa during the surveys and these are listed in Table 1, which also includes the taxonomic naming authorities and the abbreviations used throughout the text. The depth distributions of the most abundant species (>5\% total cover) at each depth and habitat are shown in Fig. 3. Along the transects running from 0 to $5 \mathrm{~m}$ in exposed shores, we found 3 species of Cystoseira that were abundant at all sites and were subsequently used in the feeding experiments: C. compressa, C. stricta and C. balearica (Fig. 3A). In the transects running from 0.2 to $5 \mathrm{~m}$ in sheltered shores we found 3 species that were abundant at all sites and were subsequently used in feeding experiments: $C$. pustulata, C. crinita and C. balearica (Fig. 3B), as well as one additional species that was abundant at 2 of the sites, $C$. tenuior (Fig. 3B). At the deep habitat, overall algal cover was very low (average total algal cover percentage across all sites was $8.69 \pm 0.95 \%$ ). C. spinosa was the only deep species that was abundant at all sites and was subsequently used in reciprocal in situ feeding experiments (Fig. 3C). In the shallow habitats contiguous to the deep sites, C. balearica was abundant at all sites and was subsequently used in the feeding experiments, but we also found small amounts of $C$. pustulata at Cap de Cavalleria and Sa Nitja (Fig. 3C). 


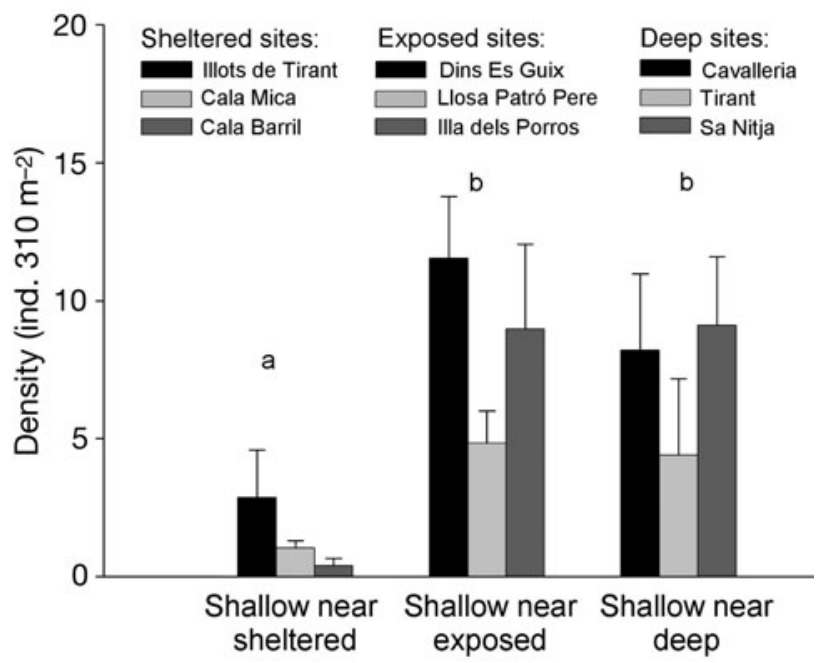

Fig. 4. Sarpa salpa. Fish density at the shallow rocky bottoms at $5 \mathrm{~m}$ contiguous to sheltered, exposed and deep habitats. Bars labelled with a different lower-case letter differ significantly. Values are means $+\mathrm{SE}$

Sarpa salpa was present only at the shallow sites (5 m depth) adjacent to all other habitat types. No adult fish were observed at $0 \mathrm{~m}$ in the wave exposed habitat, $0.2 \mathrm{~m}$ in the sheltered shores or $40 \mathrm{~m}$ depth in the deep habitats. When we compared fish densities at the shallow sites contiguous to all other habitat types, we found no differences between the shallow sites contiguous to either exposed or deep sites (Fig. 4, Table 2), whereas we found significantly lower fish densities at the shallow sites contiguous to sheltered habitats (Fig. 4, Table 2; SNK test, $\mathrm{p}<0.04$ for both comparisons).

\section{Reciprocal in situ feeding experiments}

When the most abundant Cystoseira spp. from the exposed $(0 \mathrm{~m})$ and deep habitats $(40 \mathrm{~m})$ were placed in a shallow habitat at $5 \mathrm{~m}$ depth with high Sarpa salpa
Table 2. 2-factor nested ANOVA assessing the differences in fish densities between sites and amongst the shallow habitats at $5 \mathrm{~m}$ depth contiguous to exposed habitats, sheltered habitats and deep water. Sample size $n=6$. Significant values at $p<0.05$ are in bold text. All data $\log (x+1)$ transformed to conform to parametric test assumptions

\begin{tabular}{|lrrrc|}
\hline Source of variation & df & MS & \multicolumn{1}{c|}{$F$} & $\mathrm{p}$ \\
\hline Contiguous habitat type & 2 & 2.299 & 10.155 & $\mathbf{0 . 0 1 2}$ \\
Site (Contiguous habitat type) & 6 & 0.226 & 1.956 & 0.088 \\
Residual & 54 & 0.116 & & \\
\hline
\end{tabular}

densities, a significant proportion of algal biomass was rapidly consumed within 24 and $48 \mathrm{~h}$, respectively (Fig. 5A,C). In contrast, experimental transplant depth had no effect on those Cystoseira spp. from the sheltered habitat, which were similarly consumed at 0.2 and $5 \mathrm{~m}$ (Fig. 5B). The highest consumption values were measured in those Cystoseira spp. that dominated the exposed habitat (C. stricta and C. Compressa), which rapidly lost over $70 \%$ of their initial biomass when placed in 'destination' shallow sites at $5 \mathrm{~m}$ for $24 \mathrm{~h}$ (Fig. 5; significant species by experimental depth interaction in Table 3; SNK test, $\mathrm{p}<0.01$ for all comparisons). In contrast, all species placed in their 'origin' experimental depth (5 $\mathrm{m}$ for $C$. balearica and $0 \mathrm{~m}$ for C. stricta and C. compressa) lost less than $20 \%$ of their initial biomass to consumers (Fig. 5).

Similarly, placing the deep-water species C. spinosa in a 'destination' shallow habitat with high fish density at $5 \mathrm{~m}$ also resulted in consumption of a substantial amount of biomass (Fig 5; significant Species $\times$ Depth interaction in Table 3). At $5 \mathrm{~m}$ depth, C. spinosa lost over $40 \%$ of its initial biomass to consumers, significantly more than $C$. balearica (SNK test, p < 0.05). Differences in consumption varied with site, with both Cavalleria and Sa Nitja sites having higher consumption values than did the Tirant site (SNK test, $\mathrm{p}<0.05$ ). These responses were observed after a longer transplant time of $48 \mathrm{~h}$.

Table 3. Reciprocal in situ feeding experiment results from the 3-way ANOVAs assessing differences in biomass loss in each habitat between sites, experimental transplant depths and Cystoseira species. All data were log-transformed prior to analyses. Significant probability values at $\mathrm{p}<0.05$ are in bold text

\begin{tabular}{|c|c|c|c|c|c|c|c|c|c|c|c|c|}
\hline \multirow[b]{2}{*}{ Source } & \multicolumn{4}{|c|}{ Exposed $(0 \mathrm{~m})$} & \multicolumn{4}{|c|}{ Sheltered $(0.2 \mathrm{~m})$} & \multicolumn{4}{|c|}{ Deep (40 m) } \\
\hline & df & MS & $F$ & $\mathrm{p}$ & $\mathrm{df}$ & MS & F & $\mathrm{p}$ & $\mathrm{df}$ & $\mathrm{MS}$ & $F$ & $\mathrm{p}$ \\
\hline Species & 2 & 5.151 & 17.30 & 0.011 & 2 & 0.591 & 11.88 & 0.021 & 1 & 0.034 & 63.692 & 0.015 \\
\hline Depth & 1 & 19.536 & 449.39 & 0.002 & 1 & 0.017 & 0.13 & 0.745 & 1 & 0.023 & 193.54 & 0.005 \\
\hline Site & 2 & $7.7 \times 10^{-3}$ & 0.05 & 0.950 & 2 & 0.039 & 0.81 & 0.448 & 2 & 0.003 & 3.549 & 0.032 \\
\hline Depth $\times$ Site & 2 & 0.044 & 0.29 & 0.748 & 2 & 0.126 & 2.59 & 0.078 & 2 & $0.1 \times 10^{-3}$ & 0.16 & 0.852 \\
\hline Site $\times$ Species & 4 & 0.298 & 1.99 & 0.097 & 4 & 0.050 & 1.02 & 0.397 & 2 & $0.5 \times 10^{-3}$ & 0.73 & 0.484 \\
\hline Species $\times$ Depth & 2 & 6.813 & 44.42 & 0.002 & 2 & 0.013 & 0.43 & 0.677 & 1 & 0.021 & 22.49 & 0.042 \\
\hline Species $\times$ Depth $\times$ Site & 4 & 0.153 & 1.03 & 0.395 & 4 & 0.031 & 0.63 & 0.641 & 2 & $0.9 \times 10^{-3}$ & 1.26 & 0.289 \\
\hline Residual & 162 & 0.149 & & & 162 & 0.049 & & & 108 & $0.7 \times 10^{-3}$ & & \\
\hline
\end{tabular}



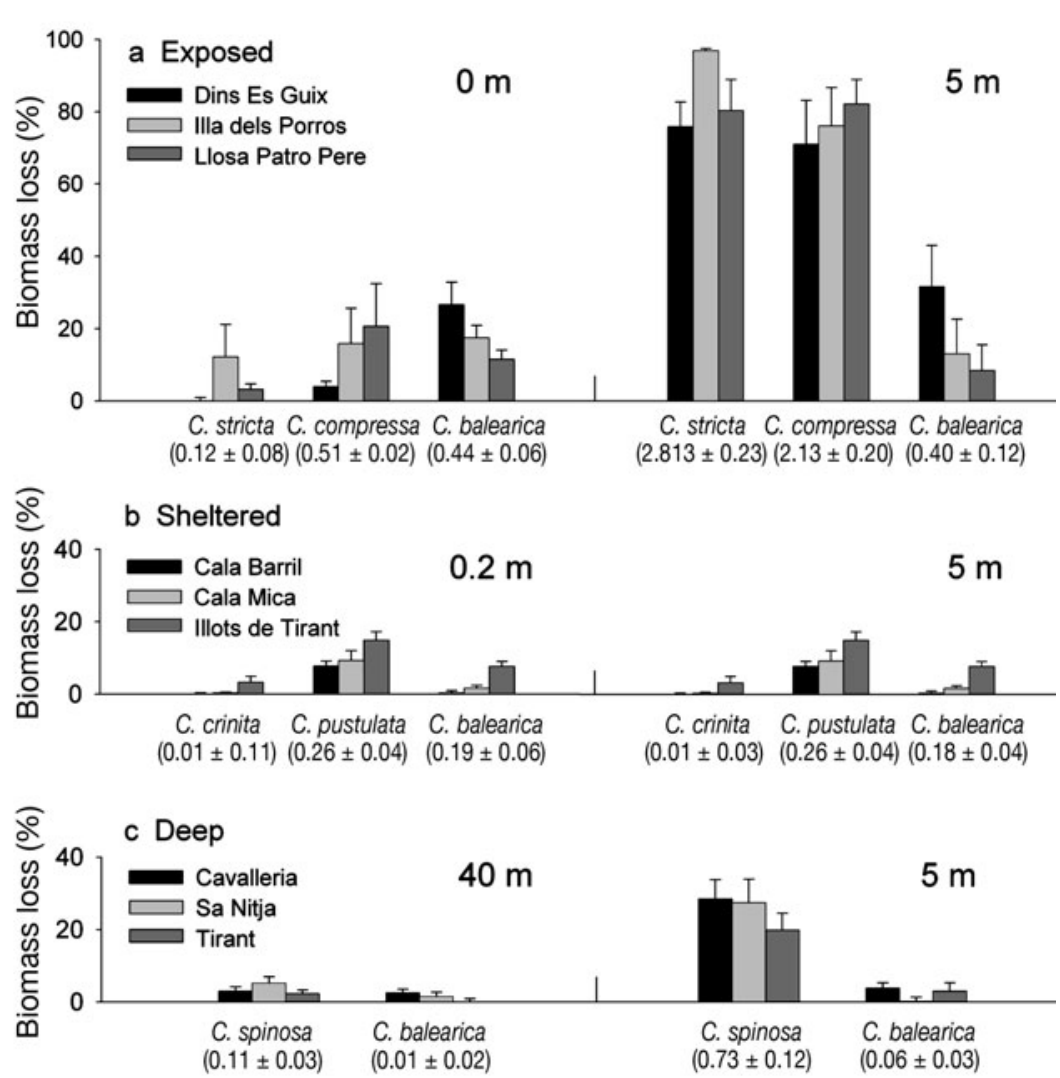

Fig. 5. Cystoseira spp. Algal biomass loss per day at each site during the 3 reciprocal in situ feeding experiments performed. Bars show mean percentage consumption \pm SE. Values in parentheses correspond to mean biomass loss per specimen across all sites ( $g$ wet $\left.w t d^{-1}\right) \pm$ SE for all species at each depth

For those species that inhabit the submerged sheltered habitats $(0.2 \mathrm{~m})$, transplantation to shallow habitats at $5 \mathrm{~m}$ had no effect on algal consumption (Fig. 5). Differences in biomass loss varied between species but were independent of experimental transplant depth (Table 3). C. pustulata lost significantly higher amounts of biomass than C. crinita (SNK test, p < 0.05).

\section{Feeding preference assays}

When offered a choice between the seagrass Posidonia oceanica and the alga Cystoseira balearica, Sarpa salpa exhibited a 2-fold preference for the seagrass leaves (average area consumed per specimen $\pm \mathrm{SE}$ : $P$. oceanica $=10.74 \pm 2.19 \mathrm{~cm}^{2}$ versus $C$. balearica $=$ $\left.5.31 \pm 1.24 \mathrm{~cm}^{2} ; t=9.875, \mathrm{df}=18, \mathrm{p}<0.001\right)$. When we offered $S$. salpa a choice between C. compressa and C. pustulata, the fish consumed 3 times more C. compressa biomass than C. pustulata (average biomass [wet wt] consumed per specimen $\pm \mathrm{SE}$ : C. compressa $=$ $1.14 \pm 0.16 \mathrm{~g}$ versus C. pustulata $=0.39 \pm 0.10 \mathrm{~g} ; t=$ 5.085 , df $=18, \mathrm{p}<0.001$ ). Samples from both experiments were collected after $24 \mathrm{~h}$.

\section{DISCUSSION}

Fish herbivory can have a profound influence on benthic community structure in the NW Mediterranean Sea by contributing to the generation and maintenance of the vertical limits of distribution of fucoid forests. We found that Cystoseira spp. that dominate at mean sea level in wave exposed shores and in deep habitats are highly susceptible to being eaten and are, thus, restricted to spatial refuges with locally reduced herbivory (too rough or too deep, respectively). In contrast, Cystoseira spp. that are abundant in habitats available to herbivores are comparatively more resistant to consumers and a less preferred source of food when compared with other macrophytes.

The highest rates of fish herbivory were found in shallow sublittoral rocky bottoms (5 $\mathrm{m}$ depth). This is consistent with numerous other studies throughout the NW Mediterranean that show a distinct preference towards shallow waters $(<10 \mathrm{~m})$ of Sarpa salpa, the only true herbivorous fish in the area (Bell 1983, Verlaque 1990, Dufour et al. 1995). Since $C$. balearica is particularly abundant in habitats characterised by high densities of herbivorous fish, we predicted that it would be defended against herbivory by resistance mechanisms. Indeed, we found that $C$. balearica lost low amounts of biomass in all feeding experiments and was substantially less palatable than the seagrass Posidonia oceanica, which is a dominant macrophyte in adjacent habitats at the same depth. In contrast, we predicted that algae that are found exclusively in habitats where herbivorous fish are scant would be highly susceptible to being eaten. We found that transplants from exposed habitats at mean sea level and from deep waters supported this prediction, and were rapidly consumed when placed in contact with herbivorous Sarpa salpa. Species from sheltered habitats, however, lost similar small amounts of biomass to consumers at 0.2 and $5 \mathrm{~m}$. These results show that, despite the fact that no fish were counted at $0.2 \mathrm{~m}$ depth during our surveys, fish did access this habitat at both depths. Overall levels of consumption in sheltered shores were nevertheless low, and this may be partly explained by the lower fish densities found in this habitat. This is in agreement with other studies showing that in temperate systems herbivorous fish are most abundant in turbulent shallow waters (0 to $6 \mathrm{~m}$ ), as opposed to calm sheltered inlets (Meekan \& Choat 1997). However, 
since some fish did access the sheltered habitats, the low consumption values probably also reflect the relative unpalatability of these macrophytes, which was demonstrated by a feeding preference experiment where fish consumed 3 times more biomass of C. Compressa (which thrives in exposed places) than of $C$. pustulata (which appears in sheltered zones).

This difference in susceptibility to herbivory between Cystoseira spp. thriving in exposed versus sheltered environments may be partly due to the adoption of contrasting growth strategies of these algae. Many studies have documented that macrophytes with high growth rates are less defended against herbivory than slow growing species (reviewed by Cebrian \& Duarte 1994). This is explained by the fact that losses to consumers of slow growing species constitute a much larger proportion of the net growth of a plant or alga and take longer to replace, which results in a stronger selective pressure for the evolution of grazer deterrents. In the oligotrophic waters of the Mediterranean Sea, nutrient availability (i.e. nutrient concentration $\times$ hydrodynamism) is the key limiting factor for production in shallow habitats, whilst light limits growth in deeper habitats (Ballesteros 1989). The high hydrodynamism in the Cystoseira forests of exposed shores allows species thriving in these environments to maintain a high nutrient uptake enhanced by turbulence, which results in high production values (Ballesteros 1989). In contrast, the growth of seaweeds in wave sheltered calm waters is more limited by nutrients because the low rate of water renewal results in rapid nutrient depletion in the boundary layer during intense photosynthesis (Gerard 1982). Additionally, herbivores are likely to exert a stronger pressure on sheltered algal communities because these habitats are slightly deeper and always available, whereas Cystoseira spp. that inhabit wave exposed habitats are only available to fish during unpredictable calm periods when turbulence does not hinder feeding.

In our study, the lowest overall levels of herbivory were found in the circalittoral zone $(40 \mathrm{~m})$, and when we placed the deep water species Cystoseira spinosa in shallow habitats with high fish densities we observed substantial losses to herbivory within $48 \mathrm{~h}$. Nevertheless, deep water species were comparatively less palatable than the highly productive species found at $0 \mathrm{~m}$ in wave exposed shores, as the biomass of $C$. spinosa consumed per day was much lower than that of either C. compressa or C. stricta (Fig. 5). Again, this is consistent with differences in the relative growth rate of Cystoseira spp. from the distinct habitats, since deep water species grow substantially slower than algae at $0 \mathrm{~m}$ due to a decrease in light availability (Ballesteros 1989). Indeed, the degree to which a habitat serves as a spatial refuge from herbivory depends on whether the rate of algal growth exceeds the rates of consumption, and deeper areas can only serve as spatial escapes when grazing along a bathymetric gradient decreases faster than the decrease in algal production due to diminishing light (Hay 1991).

Identifying the mechanisms of resistance that underlie the observed differences in palatability among Cystoseira spp. is beyond the scope of this study, as there are multiple structural, chemical and/or nutritional mechanisms that may be at play. Nevertheless, it is worth noting that the genus Cystoseira is characterised by a high diversity of secondary metabolites (Amico 1995), some of which may have deterrent properties. Indeed, some of the species $(C$. balearica and $C$. crinita) that were consumed less than others in our study are known to produce terpenoid metabolites, which are absent from highly palatable species such as C. compressa and C. stricta (Amico 1995). Additionally, besides differences among species in constitutive chemical defences (i.e. metabolites that function independently of damage), there may also be important differences within each species in induced chemical defences (i.e. metabolites that are produced in response to herbivore attack).

In the only other study that has examined the vertical distribution pattern of Cystoseira forests in the Mediterranean Sea, Sant (2003) examined the photosynthetic characteristics of multiple Cystoseira spp. distributed along a bathymetric gradient. She found that while the lower limit of distribution of shallow water species may be influenced by a decrease in their photosynthetic capacity in low-light environments, the upper limit of distribution of these macrophytes is not determined by light availability. Our results provide powerful evidence that herbivory may strongly contribute to setting the lower limit of distribution of those shallow species that inhabit wave exposed habitats at mean sea level and the upper distributional limit of deep species, but not of those species present in calm shallow waters. Nevertheless, other mechanisms such as recruitment inhibition or competition may also play an important role in structuring the distribution of these macroalgae, as has been shown in other fucoid communities (Dayton et al. 1992, McCook 1997). Our results are consistent with other studies that show biotic variables determining the lower distributional limits of many subtidal algae (Witman 1987, Morrison 1988, Dayton et al. 1992, Scheibling et al. 1999) and the upper distributional limits of some other macrophytes (de Ruyter van Steveninck \& Breeman 1987).

Overall, our findings challenge the widely accepted view that fish herbivory has only a modest effect on structuring algal assemblages in temperate waters. While herbivorous fish are considered to have a key influence in marine tropical waters, urchins are consid- 
ered the dominant herbivores in temperate shores (Gaines \& Lubchenco 1982). This contrasting role of herbivorous fish in structuring benthic communities is often attributed to important latitudinal differences in their taxonomic diversity, as the proportion of herbivorous species decreases radically from tropical to temperate waters (Horn 1989, Floeter et al. 2005). However, herbivorous fish that make a small proportion of the overall number of fish species in temperate systems can make up a substantial proportion of the total fish biomass (Jones 1988, F. Tomas unpubl.). The NW Mediterranean Sea provides a particularly dramatic example of this pattern, since there is only one strictly herbivorous fish species, Sarpa salpa, but it can make up over $50 \%$ of the total fish biomass in some habitats within unexploited marine protected areas (Macpherson et al. 2002). Furthermore, recent studies show that the effect of $S$. salpa on benthic macrophytes is particularly large, as this fish can consume over $40 \%$ of the annual above ground primary production of shallow seagrass beds (Prado et al. 2007). Our findings experimentally confirm those of Verlaque (1990) and Sala (1996), who examined the gut contents of $S$. salpa and concluded that this species is a very selective fish that may strongly influence the composition and distribution of Mediterranean algal communities. This study, thus, reinforces the role of $S$. salpa as a key primary consumer and highlights the need to reassess the functional importance of herbivorous fishes in temperate systems.

Acknowledgements. We thank A. Grau, technical head of the Marine Resources Services of the Conselleria d'Agricultura i Pesca del Govern de les Illes Balears, and the rangers F. Ripoll and D. López-Luna for giving us access to the Nord de Menorca MPA. Several CEAB students and staff kindly helped during fieldwork. We thank E. Sala for insightful comments and discussion, and 3 anonymous reviewers for significantly enhancing the quality of the manuscript. This work was partially supported by a FPI Postgraduate Award to A.V. from the Spanish Ministry of Science and Education (REN2002-04020-C02).

\section{LITERATURE CITED}

Airoldi L (2000) Effects of disturbance, life histories, and overgrowth on coexistence of algal crusts and turfs. Ecology 81:798-814

Amico V (1995) Marine brown algae of Family Cystoseiraceae: chemistry and chemotaxonomy. Phytochemistry 39: 1257-1279

Ballesteros E (1989) Production of seaweeds in Northwestern Mediterranean marine communities: its relation with environmental factors. Sci Mar 52:357-364

Ballesteros E (1992) Els vegetals i la zonació litoral: espècies, comunitats i factors que influeixen en la seva distribució. Arxius de la Secció de Ciències, Institut d'Estudis Catalans 101, Barcelona

Ballesteros E, Cebrian E (2004) Estudi sobre la diversitat, bionomia bentònica i cartografia de la reserva del Nord de Menorca. Informe Tècnic, Govern de les Illes Balears, Conselleria d'Agricultura i Pesca, Palma de Mallorca

Ballesteros E, Romero J (1988) Zonation patterns in tideless environments (Northwestern Mediterranean): looking for discontinuities in species distributions. Investig Pesq 52: 595-616

Ballesteros E, Zabala M (1993) El Bentos: el marc físic. In: Alcover J, Ballesteros E, Fornós J (eds) Història natural de l'Arxipèlag de Cabrera. CSIC-Ed, Palma de Mallorca, p 663-685

Ballesteros E, Zabala M, Uriz MJ, Garcia-Rubies A, Turon X (1993) El Bentos: les comunitats. In: Alcover J, Ballesteros E, Fornós J (eds) Història natural de l'Arxipèlag de Cabrera. CSIC-Ed, Palma de Mallorca, p 687-730

Ballesteros E, Sala E, Garrabou J, Zabala M (1998) Community structure and frond size distribution of a deep water stand of Cystoseira spinosa (Phaeophyta) in the Northwestern Mediterranean. Eur J Phycol 33:121-128

Bell JD (1983) Effects of depth and marine reserve fishing restrictions on the structure of a rocky reef fish assemblage in the Northwestern Mediterranean Sea. J Appl Ecol 20:357-369

> Benedetti-Cecchi L, Bulleri F, Cinelli F (2000) The interplay of physical and biological factors in maintaining mid-shore and low-shore assemblages on rocky coasts in the northwest Mediterranean. Oecologia 123:406-417

Boudouresque C, Ballesteros E, Ben Maiz N, Boisset F and others (1990) Livre Rouge 'Gérard Vuignier' des végétaux, peuplements et paysages marins menacés de Méditerranée. In: MAP Technical Report Series, Vol 43, PNUE, Athens, p 250

Briggs JC (2007) Marine biogeography and ecology: invasions and introductions. J Biogeogr 34:193-198

Burkepile DE, Hay ME (2006) Herbivore vs. nutrient control of marine primary producers: context-dependent effects. Ecology 87:3128-3139

Cebrian J, Duarte CM (1994) The dependence of herbivory on growth rate in natural plant communities. Funct Ecol 8:518-525

Chelazzi G, Serra G, Bucciarelli G (1997) Zonal recovery after experimental displacement in two sea urchins co-occurring in the Mediterranean. J Exp Mar Biol Ecol 212:1-7

Cyr H, Pace ML (1993) Magnitude and patterns of herbivory in aquatic and terrestrial ecosystems. Nature 361:148-150

Dayton PK (1972) Toward an understanding of community resilience and the potential effects of enrichments to the benthos of McMurdo Sound, Antarctica. In: Parker BC (ed) Proceedings of the colloquium on conservation problems in Antarctica. Allen Press, Lawrence, KS, p 81-95

> Dayton PK, Tegner MJ, Parnell PE, Edwards PB (1992) Temporal and spatial patterns of disturbance and recovery in a kelp forest community. Ecol Monogr 62:421-445

> de Ruyter van Steveninck ED, Breeman AM (1987) Deepwater populations of Lobophora variegata (Phaeophyceae) on the coral reef of Curaçao: influence of grazing and dispersal on distribution patterns. Mar Ecol Prog Ser 38: $241-250$

> Dufour V, Jouvenel JY, Galzin R (1995) Study of a Mediterranean reef fish assemblage. Comparisons of population distributions between depths in protected and unprotected areas over one decade. Aquat Living Resour 8: $17-25$

Feldmann J (1937) Recherches sur la végétation marine de la Méditerranée: la côte des Albères. Wolf, Rouen

Floeter SR, Behrens MD, Ferreira CEL, Paddack MJ, Horn $\mathrm{MH}$ (2005) Geographical gradients of marine herbivorous fishes: patterns and processes. Mar Biol 147:1435-1447 
Gaines SD, Lubchenco J (1982) A unified approach to marine plant-herbivore interactions. II. Biogeography. Annu Rev Ecol Syst 13:111-138

Gaylord B, Gaines SD (2000) Temperature or transport? Range limits in marine species mediated solely by flow. Am Nat 155:769-789

Gerard VA (1982) In situ water motion and nutrient uptake by the giant kelp Macrocystis pyrifera. Mar Biol 69:51-54

Giaccone G (1973) Elementi di Bot Mar. I. Bionomia bentonica e vegetazione sommersa del Mediterraneo. Pubbl Ist Bot, University Trieste, serie didattica:1-41

Giaccone G, Bruni A (1973) Le Cystoseire e la vegetazione sommersa del Mediterraneo. Atti Ist Ven Sci Lett Art 131: 59-103

Guiry MD, Guiry GM (2008) AlgaeBase. World-wide electronic publication. National University of Ireland, Galway. www.algaebase.org (accessed 14 May 2008)

Hay ME (1991) Fish-seaweed interactions on coral reefs: effects of herbivorous fishes and adaptations of their prey. In: Sale P (ed) The ecology of fishes on coral reefs. Academic Press, San Diego, CA, p 96-119

> Hay ME, Colburn T, Downing D (1983) Spatial and temporal patterns in herbivory on a Caribbean fringing reef: the effects on plant distribution. Oecologia 58:299-308

Hereu B (2004) The role of trophic interactions between fishes, sea urchins and algae in the northwest Mediterranean rocky infralittoral. $\mathrm{PhD}$ thesis, Universitat de Barcelona

Hereu B (2006) Depletion of palatable algae by sea urchins and fishes in a Mediterranean subtidal community. Mar Ecol Prog Ser 313:95-103

Horn MH (1989) Biology of marine herbivorous fishes. Oceanogr Mar Biol Annu Rev 27:167-272

> Hutchins L (1947) The bases for temperature zonation in geographical distribution. Ecol Monogr 17:325-335

Jones GP (1988) Ecology of rocky reef fish of north-eastern New Zealand: a review. N Z J Mar Freshw Res 22:445-462

Little C, Kitching JA (1996) The biology of rocky shores. Oxford University Press, Oxford

Lubchenco J, Gaines SD (1981) A unified approach to marine plant-herbivore interactions. 1. Populations and communities. Annu Rev Ecol Syst 12:405-437

Macpherson E, Gordoa A, Garcia-Rubies A (2002) Biomass size spectra in littoral fishes in protected and unprotected areas in the NW Mediterranean. Estuar Coast Shelf Sci 55:777-788

McCook LJ (1997) Effects of herbivory on zonation of Sargassum spp. within fringing reefs of the central Great Barrier Reef. Mar Biol 129:713-722

Meekan MG, Choat JH (1997) Latitudinal variation in abundance of herbivorous fishes: a comparison of temperate and tropical reefs. Mar Biol 128:373-383

Micheli F, Benedetti-Cecchi L, Gambaccini S, Bertocci I, Borsini C, Osio GC, Romano F (2005) Cascading human impacts, marine protected areas, and the structure of Mediterranean reef assemblages. Ecol Monogr 75:81-102

Milchunas DG, Noy-Meir I (2002) Grazing refuges, external avoidance of herbivory and plant diversity. Oikos 99: $113-130$

Morrison D (1988) Comparing fish and urchin grazing in shallow and deeper coral-reef algal communities. Ecology 69: $1367-1382$

Peterson CH, Renaud PE (1989) Analysis of feeding preference experiments. Oecologia 80:82-86

Prado P, Tomas F, Alcoverro T, Romero J (2007) Extensive direct measurements of Posidonia oceanica defoliation confirm the importance of herbivory in temperate seagrass meadows. Mar Ecol Prog Ser 340:63-71

Quinn G, Keough M (2002) Experimental design and data analysis for biologists. Cambridge University Press, Cambridge

Ruitton S, Francour P, Boudouresque C (2000) Relationships between algae, benthic herbivorous invertebrates and fishes in rocky sublittoral communities of a temperate sea (Mediterranean). Estuar Coast Shelf Sci 50:217-230

Ruitton S, Verlaque M, Aubin G, Boudouresque CF (2006) Grazing on Caulerpa racemosa var. cylindracea (Caulerpales, Chlorophyta) in the Mediterranean Sea by herbivorous fishes and sea urchins. Vie Milieu Life Environ 56:33-41

Sala E (1996) The role of fishes in the organization of a Mediterranean sublittoral community. $\mathrm{PhD}$ thesis, Université d'Aix-Marseille II

Sala E, Ballesteros E (1997) Partitioning of space and food resources by three fish of the genus Diplodus (Sparidae) in a Mediterranean rocky infralittoral ecosystem. Mar Ecol Prog Ser 152:273-283

> Sala E, Boudouresque C (1997) The role of fishes in the organization of a Mediterranean sublittoral community. I Algal communities. J Exp Mar Biol Ecol 212:25-44

Sala E, Ribes M, Hereu B, Zabala M, Alva V, Coma R, Garrabou J (1998) Temporal variability in abundance of the sea urchins Paracentrotus lividus and Arbacia lixula in the northwestern Mediterranean: comparison between a marine reserve and an unprotected area. Mar Ecol Prog Ser 168:135-145

Sant N (2003) Algues bentòniques mediterrànies: comparació de mètodes de mostreig, estructura de comunitats i variació en la resposta fotosintètica. PhD thesis, Universitat de Barcelona

> Scheibling RE, Hennigar AW, Balch T (1999) Destructive grazing, epiphytism, and disease: the dynamics of sea urchin-kelp interactions in Nova Scotia. Can J Fish Aquat Sci 56:2300-2314

Tomas F, Turon X, Romero J (2005) Seasonal and small-scale spatial variability of herbivory pressure on the temperate seagrass Posidonia oceanica. Mar Ecol Prog Ser 301: 95-107

Underwood AJ (1997) Experiments in ecology: their logical design and interpretation using analysis of variance. Cambridge University Press, Cambridge

Verlaque M (1984) Biology of juveniles of the herbivorous sea-urchin, Paracentrotus lividus (Lamarck) - selectivity of grazing and impact on rocky algal communities in Corsica (Mediterranean, France). Bot Mar 27:401-424

Verlaque M (1987a) Contribution à l'étude du phytobenthos d'un écosystème photophile thermophile marin en Méditerranée occidentale. Étude structurale et dynamique du phytobenthos et analyse des relations Faune-Flore. PhD thesis, Université d'Aix-Marseille II

Verlaque M (1987b) Relations entre Paracentrotus lividus (Lamarck) et le phytobenthos de Mediterranée occidentale. In: Boudouresque $\mathrm{C}$ (ed) International workshop on Posidonia beds. GIS Posidonie, Marseille, p 5-36

Verlaque M (1990) Relations entre Sarpa salpa (Linnaeus, 1758) (Téléostéen, Sparidae), les autres poissons broteurs et le phytobenthos algal méditerranéen. Oceanol Acta 13:373-388

Witman JD (1987) Subtidal coexistence-storms, grazing, mutualism, and the zonation of kelps and mussels. Ecol Monogr 57:167-187

Witman JD, Dayton PK (2001) Rocky subtidal communities. In: Bertness MD, Gaines SD, Hay ME (eds) Marine community ecology. Sinauer Associates, Sunderland

Zabala M, Ballesteros E (1989) Surface-dependent strategies and energy flux in benthic marine communities or, why corals do not exist in the Mediterranean. Sci Mar 53:1-15 